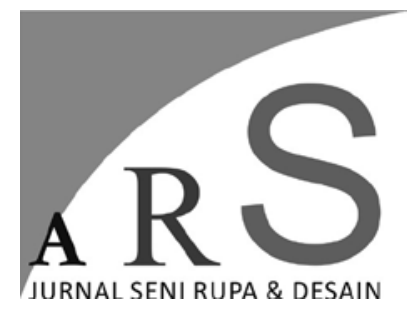

Vol 24 No 1 Januari - Maret 2021 33-42

\section{OPTIMALISASI PEMBELAJARAN SENI GRAFIS BAGI GURU SENI BUDAYA SE-KAWEDANAN JATINOM, KLATEN, JAWA TENGAH}

\author{
Devy Ika Nurjanah ${ }^{1}$, Nizar Mohamad Afandi ${ }^{2}$ \\ 1,2 Jurusan Seni Murni, Fakultas Seni Rupa, Institut Seni Indonesia Yogyakarta \\ E-mail: devyikanurjanah@gmail.com
}

\begin{abstract}
ABSTRAK
Kelompok MGMP (Musyawarah Guru Mata Pelajaran) seni budaya SMP seKawedanan Jatinom merupakan wadah para guru mata pelajaran seni budaya untuk meningkatkan mutu dan kualitas pembelajaran. Kelompok ini berlatarbelakang guru-guru seni budaya dari berbagai disiplin ilmu. Keterbatasan asal disiplin ilmu tentunya tidak seharusnya menjadi kendala dalam memberikan materi pembelajaran di kelas, apalagi dalam penyampaian materi pembelajaran seni grafis. Tujuan penelitian yaitu mengoptimalkan kompetensi guru seni budaya dalam mengajarkan materi seni grafis kepada siswa. Metode pengumpulan data dalam penelitian ini adalah metode kualitatif, dengan cara observasi langsung, dokumentasi, kuesioner dan wawancara. Subjek penelitian adalah guru seni budaya SMP se-Kawedanan Jatinom, Klaten, Jawa Tengah yang pernah atau sedang memberikan materi seni grafis di kelas IX semester II. Luaran dari penelitian ini yaitu akan disusun buku bahan ajar seni grafis bagi guru seni budaya SMP. Dengan bahan ajar tersebut diharapkan para guru dapat menambah ilmu tentang seni grafis dan memudahkan penyampaianya pada siswa. Penelitian ini diharapkan dapat bermanfaat dalam mengembangkan pengetahuan seni grafis kepada guru dan siswa sejak dini, sehingga nantinya seni grafis lebih dikenal masyarakat luas.
\end{abstract}

Kata kunci: seni grafis, seni murni, pembelajaran, guru seni budaya

\begin{abstract}
Optimization of Graphics Arts Learning for Cultural Arts Teachers in Jatinom, Klaten, Central Java. The MGMP (Subject Teacher Deliberation) group for the arts and culture of SMP as Kawedanan Jatinom is a forum for teachers of cultural arts subjects to improve the quality and quality of learning. This group has a background of cultural arts teachers from various disciplines. The limitations of the origin of scientific disciplines, of course, should not be an obstacle in providing learning material in class, especially in the delivery of graphic arts learning materials. The research objective is to optimize the competence of cultural arts teachers in teaching graphic arts materials to students. The data collection method in this study is a qualitative method, by means of direct observation, documentation, questionnaires and interviews. The research subject was a junior high school cultural arts teacher in Kawedanan Jatinom, Klaten, Central Java who had or was giving graphic art material in class IX semester II. The output of this research is a book of graphic arts teaching materials for junior high school cultural arts teachers. With this teaching material, it is hoped that the teachers can add knowledge about graphic arts and make it easier to convey it to students. This research is expected to be useful in developing graphic arts knowledge for teachers and students from an early age, so that later graphic arts will be better known to the wider community.
\end{abstract}

Keywords: printmaking, fine art, learning, cultural arts teacher 


\section{Pendahuluan}

Seni grafis atau dalam bahasa Inggris printmaking (seni cetak mencetak), merupakan cabang seni rupa murni dua dimensi, yang dalam proses pembuatan karya ini dengan cara dicetak. Dalam pembuatan karya seni grafis dibutuhkan acuan cetak/klise cetak yang dibuat menggunakan teknik tertentu. Apa saja media yang dapat dimanfaatkan sebagai perantara cetak dapat disebut dengan klise atau matrix. Klise inilah yang diolah sebelum dilakukan proses mencetak. Artinya dengan adanya klise, dimungkinkan bagi seniman untuk menghasilkan karya ciptaannya dalam bentuk serial atau dengan perkataan lain, gambar atau tulisan yang sama bisa digandakan. (Sandra, 2012) Misalnya acuan cetak yang digunakan adalah papan kayu, MDF (Middle Density Fibreboard), karet fiber linoleum (lino), plat tembaga, plat alunimium, screen sablon. Permukaan klise cetak dibubuhi tinta dan diperbanyak dengan cara dicetak dengan alat press khusus pada permukaan 2 dimensi, biasanya pada permukaan kertas. Hasil cetakan dapat diperbanyak namun setiap salinan harus diberi keterangan identitas karya dan urutan penomoran cetakan. Hal ini dapat diartikan bahwa setiap salinan bersifat otentik, sama halnya dengan lukisan. Sehingga seni grafis (printmaking) dapat dikategorikan ke dalam seni rupa murni, seperti seni lukis dan seni patung.

Berbeda dengan pengertian desain grafis pada jurusan Desain Komunikasi Visual yaitu kegiatan merancang/desain gambar menggunakan teknologi komputer, sedangkan seni grafis (printmaking) merupakan proses mencetak dengan cara manual dan tidak mengikuti perkembangan teknologi. $\mathrm{Hal}$ ini kurang dipahami oleh masyarakat sehingga banyak yang keliru, sama halnya dengan mahasiswa baru di Fakultas Seni Rupa, Institut Seni Indonesia (ISI) Yogyakarta yang banyak mengaku salah mengambil Jurusan Di Seni Murni minat utama seni grafis. Menurut pemahaman mereka, seni grafis di Jurusan Seni Murni sama dengan desain grafis di Jurusan Desain Komunikasi Visual. Di seni murni sendiri, seni grafis masih dianggap sebagai seni nomor dua, seperti yang diungkapkan dalam buku katalog Bentara Budaya berjudul Setengah Abad Seni Grafis Indonesia, Half a Century of Indonesian Printmaking, perjalanan seni grafis di Indonesia seringkali dilihat sebagai perjalanan praktek seni rupa "pinggiran," yang tertinggal jauh di belakang perkembangan seni lukis dan patung yang sudah umum diterima sebagai wujud seni rupa yang paling "tulen." Situasi ini belum juga berubah sampai di penghujung abad 20 yang baru lampau (Bentara Budaya Jakarta, 2000). Hingga sekarang seni grafis juga belum begitu dikenal masyarakat dan keberadaannya tidak begitu dikenal seperti seni lukis dan seni patung.

Seni grafis masih sangat perlu dikenalkan kepada masyarakat khususnya siswa, agar sejak dini mempunyai pemahaman tentang seni grafis sehingga dapat memperkaya pengetahuan dalam bidang seni rupa. Pada kurikulum 2013, seni grafis sudah masuk dalam materi pembelajaran Seni Budaya SMP kelas 9. Dalam penyampaian materi pembelajaran seni grafis juga dibutuhkan guru yang berkompeten serta menguasai materi. Kendala yang dihadapi saat ini yaitu guru seni budaya SMP sebagian besar terdiri dari berbagai disiplin ilmu seni, yaitu: sarjana pendidikan seni dengan bidang seni rupa, seni musik, seni tari, dan juga seni drama. Setiap guru dapat memilih dua aspek yang dikuasai dalam dua semester, misal pada kelas 9 semester pertama yang diajarkan seni musik, lalu pada semester dua harus berbeda aspek seni, misal seni rupa. Materi pembelajaran seni rupa juga mempunyai beberapa sub materi yang harus diajarkan, yaitu seni lukis, seni patung dan seni grafis. Guru seni budaya berlatar belakang seni rupa juga tidak sepenuhnya menguasai ketiga sub materi tersebut. Hal ini tentu berpengaruh terhadap kualitas pengajaran kepada siswa khususnya materi seni grafis. Maka dalam penelitian ini diharapkan adanya solusi dari permasalahan tersebut, dengan merancang model pembelajaran berupa buku bahan ajar tutorial seni grafis alternatif dengan alat dan bahan sederhana. Hal ini diharapkan agar guru dapat dengan mudah menyampaikan materi seni grafis kepada 
siswa dan siswa dapat memahami dan mengerjakan tugas secara tuntas. Sehingga seni grafis dapat dikenal oleh siswa sejak dini dan diharapkan mereka mempunyai ketertarikan untuk berkarya dan memperdalam teknik seni grafis ditingkat perguruan tinggi nantinya, khususnya minat untuk masuk di Jurusan Seni Murni, ISI Yogyakarta.

Berdasarkan uraian di atas, dapat dirumuskan pertanyaan bagaimana merancang model pembelajaran sebagai pemahaman dasar seni grafis bagi Guru Seni Budaya SMP se-Kawedanan Jatinom, Klaten, Jawa Tengah. Tujuan dari pelaksanaan penelitian yaitu untuk mendapatkan model pembelajaran mengenai pemahaman dasar seni grafis bagi guru seni budaya di SMP seKawedanan Jatinom dalam mengajarkan materi seni grafis kepada siswa, sebagai bentuk optimalisasi pembelajaran seni grafis. Sedangkan manfaat penelitian ini adalah agar hasilnya dapat dijadikan bahan rujukan terhadap penelitianpenelitian berikutnya, yaitu mengenai pembelajaran seni grafis. Hasil penelitian ini sebagai sarana publikasi ilmiah sehingga seni grafis dapat lebih dipahami dan dikenal oleh masyarakat, khususnya guru dan siswa.

\section{Bahan dan Metode Penelitian}

Penelitian dengan subjek guru seni budaya terhadap pembelajaran seni grafis di SMP belum pernah dilakukan, sebagian besar penelitian seni grafis menelaah salah satu teknik seni grafis dengan subjek pelajar atau siswa di salah satu sekolah. Penelitian ini tidak mendalami salah satu teknik seni grafis, tetapi membahas tentang teori seni grafis yang disesuaikan dengan kurikulum SMP kelas 9 semester 2. Berdasarkan kurikulum 2013, mata pelajaran Seni Budaya di SMP terdiri dari seni rupa, seni musik, seni tari dan seni teater (Kementerian Pendidikan dan Kebudayaan, 2017).

Dalam Lampiran Peraturan Menteri Pendidikan Nasional Nomor 22 Tahun 2006 dijelaskan, kurikulum mengamanatkan bahwa setiap satuan pendidikan dapat memilih aspek yang diajarkan sesuai dengan kemampuan (guru dan fasilitas) pada satuan Pendidikan tersebut. Pada mata pelajaran seni budaya, guru dapat memilih dua aspek yang dikuasai dalam dua semester, misal pada kelas 9 semester pertama yang diajarkan seni musik, lalu pada semester dua harus berbeda aspek seni, misal seni rupa. Seni grafis dapat dijumpai pada kelas 9 dalam mata pelajaran seni rupa semester II. Permendikbud Tahun 2016 Nomor 024 Lampiran 38, Kompetensi Dasar Pengetahuan yang hendak dicapai (point 3.3, kolom yang diberi tanda kotak merah) adalah memahami prosedur berkarya seni grafis dengan berbagai bahan dan teknik. Serta dalam Kompetensi Dasar Ketrampilan yang ditetapkan (point 4.3) adalah membuat karya seni grafis dengan berbagai bahan dan teknik. Hal tersebut akan menjadi acuan dalam penelitian ini.

Lihat pada Tabel 1 yang tertera adalah silabus seni budaya kelas 9 semester yang digunakan oleh guru sebagai pedoman dalam penyusunan rencana pembelajaran seni grafis. Buku Guru Seni Budaya Kelas 9 sebagai pedoman guru, serta buku paket siswa Seni Budaya kelas 9 yang diterbitkan oleh Kemendikbud berisi materi yang lebih detail. Pada prakteknya guru seni budaya biasanya memilih salah satu teknik seni grafis yang akan ditugaskan kepada siswa. Berikut adalah silabus seni budaya kelas IX semester yang digunakan oleh guru sebagai pedoman dalam penyusunan rencana pembelajaran seni grafis. Buku Guru Seni Budaya Kelas 9 sebagai pedoman guru, serta buku paket siswa Seni Budaya kelas IX yang diterbitkan oleh Kemendikbud berisi materi yang lebih detail. Pada prakteknya guru seni budaya biasanya memilih salah satu teknik seni grafis yang akan ditugaskan kepada siswa. Namun terkadang teknik yang diajarkan kurang sesuai dengan teori seni grafis. Hal ini juga perlu ditelaah dalam penelitian ini. Kajian pustaka yang berkaitan dengan teori seni grafis dijelaskan dalam beberapa buku, yaitu: Setengah Abad Seni Grafis Indonesia, Half a Century of Indonesian Printmaking oleh Bentara Budaya Jakarta. Buku katalog yang diterbitkan Bentara budaya tersebut berisi sejarah dan teori seni grafis, serta perkembangan seni grafis. 
Selain itu buku berjudul Cap Jempol, Seni Cetak Grafis Dari Nol yang ditulis oleh AC Andre Tanama juga menjadi acuan dan referensi dalam penelitian ini, buku tersebut membahas mengenai pengertian, hakikat seni grafis, serta pengetahuan berbagai teknik seni cetak grafis, dari teknik cetak tinggi, teknik cetak dalam, teknik cetak datar, dan teknik cetak saring.
Dalam buku ini juga dijelaskan proses membuat karya teknik seni grafis cetak tinggi secara rinci. Kajian pustaka mengenai jenis-jenis teknik cetak seni grafis alternatif juga dijelaskan dalam buku berjudul Printmaking: How to Print Anything on Everything oleh Christine Medley dan berbagai referensi dari Youtube dan website.

Tabel 1. Silabus Seni Budaya SMP Kurikulum 2013.

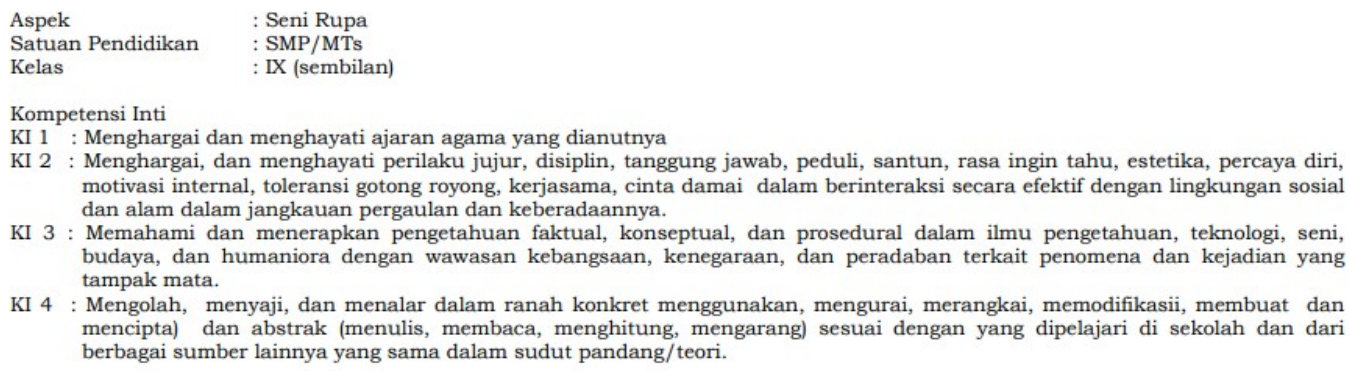

KI 2 : Menghargai, dan menghayati perilaku jujur, disiplin, tanggung jawab, peduli, santun, rasa ingin tahu, estetika, percaya diri, motivasi internal, toleransi gotong royong, kerjasama, cinta damai dalam berinteraksi secara efektif dengan lingkungan sosial dan alam dalam jangkauan pergaulan dan keberadaannya.

KI 3 : Memahami dan menerapkan pengetahuan faktual, konseptual, dan prosedural dalam ilmu pengetahuan, teknologi, seni, budaya, dan humaniora dengan wawasan kebangsaan, kenegaraan, dan peradaban terkait penomena dan kejadian yang tampak mata.

KI 4 : Mengolah, menyaji, dan menalar dalam ranah konkret menggunakan, mengurai, merangkai, memodifikasii, membuat dan mencipta) dan abstrak (menulis, membaca, menghitung, mengarang) sesuai dengan yang dipelajari di sekolah dan dari berbagai sumber lainnya yang sama dalam sudut pandang/teori.

\begin{tabular}{|c|c|c|c|c|c|c|}
\hline & Kompetensi Dasar & Materi Pembelajaran & Kegiatan Pembelajaran & Penilaian & $\begin{array}{l}\text { Alokasi } \\
\text { Waktu }\end{array}$ & $\begin{array}{l}\text { Sumber } \\
\text { Belajar }\end{array}$ \\
\hline 1.1 & $\begin{array}{l}\text { Menerima, menanggapi } \\
\text { dan menghargai } \\
\text { keragaman dan } \\
\text { keunikan karya seni } \\
\text { rupa modern sebagai } \\
\text { bentuk rasa syukur } \\
\text { terhadap anugerah }\end{array}$ & & $\begin{array}{l}\text { Pembelajaran KI } 1 \text { dan KI } 2 \\
\text { dilakukan secara tidak langsung } \\
\text { (terintegrasi) dalam pembelajaran KI } \\
3 \text { dan KI } 4\end{array}$ & $\begin{array}{l}\text { Penilaian KI } 1 \text { dan } \\
\text { KI } 2 \text { dilakukan } \\
\text { melalui : } \\
\text { - Observasi, } \\
\text { - Penilaian diri, } \\
\text { - Penilaian teman } \\
\text { sejawat oleh peserta }\end{array}$ & & \\
\hline
\end{tabular}

$-1031-$

\begin{tabular}{|c|c|c|c|c|c|c|}
\hline & Kompetensi Dasar & Materi Pembelajaran & Kegiatan Pembelajaran & Penilaian & $\begin{array}{l}\text { Alokasi } \\
\text { Waktu }\end{array}$ & $\begin{array}{l}\text { Sumber } \\
\text { Belajar }\end{array}$ \\
\hline 2.1 & $\begin{array}{l}\text { Tuhan } \\
\text { Menunjukkan sikap } \\
\text { menghargai,jujur, disiplin, } \\
\text { melalui aktivitas } \\
\text { berkesenian }\end{array}$ & & & \begin{tabular}{|l|} 
didik, \\
- Jurnal
\end{tabular} & & \\
\hline 2.2 & $\begin{array}{l}\text { Menunjukkan sikap } \\
\text { bertanggung jawab, } \\
\text { peduli, santun terhadap } \\
\text { karya seni rupa dan } \\
\text { pembuatnya } \\
\text { Menunjukkan sikap } \\
\text { percaya diri, motivasi } \\
\text { internal, kepedulian } \\
\text { terhadap lingkungan } \\
\text { dalam berkarya seni }\end{array}$ & & & & & \\
\hline 4.1 . & $\begin{array}{l}\text { Memahami konsep dan } \\
\text { prosedur karya seni lukis } \\
\text { dengan beragam media } \\
\text { dan teknik } \\
\text { Membuat karya seni } \\
\text { lukis dengan beragam } \\
\text { media dan teknik }\end{array}$ & $\begin{array}{l}\text { Seni lukis dengan } \\
\text { beragam media dan } \\
\text { teknik }\end{array}$ & $\begin{array}{l}\text { Mengamati } \\
\text { - Melihat lukisan dengan berbagai } \\
\text { teknik dan media yang berbeda } \\
\text { - Membaca buku tentang konsep dan } \\
\text { prosedur melukis } \\
\text { Menanya } \\
\text { - Menanyakan media yang murah yang } \\
\text { dapat digunakan dalam melukis } \\
\text { - Menanyakan teknik melukis } \\
\text { dengan bahan krayon, cat air dan cat } \\
\text { minyak } \\
\text { Mengumpulkan Informasi } \\
\text { - Menghubungkan antara konsep dan } \\
\text { prosedur menggambar dalam aliran } \\
\text { seni rupa } \\
\text { - Mencari konsep dan prosedur } \\
\text { membuat gambar }\end{array}$ & \begin{tabular}{|l} 
Sikap: \\
- Observasi. \\
Tentang perilaku \\
peserta didik dalam \\
hal keriasama, \\
kedisipilan, \\
kebersihan, penuh \\
perhatian dalam \\
membuat karya seni \\
lukis dengan \\
beragam media dan \\
teknik. \\
\\
Pengetahuan: \\
- Penugasan \\
Membuat \\
ringkasan tentang \\
prosedur \\
\end{tabular} & $12 \mathrm{JP}$ & $\begin{array}{l}\text { - Buku } \\
\text { Teks } \\
\text { Pelajaran } \\
\text { Seni } \\
\text { Budaya } \\
\text { Kelas IX } \\
\text { - Buku- } \\
\text { buku lain } \\
\text { yang } \\
\text { relevan } \\
\text { - Informasi } \\
\text { melalui } \\
\text { internet } \\
\text { - Pameran } \\
\text { karya seni } \\
\text { Rupa AC }\end{array}$ \\
\hline
\end{tabular}

-1032 - 


\begin{tabular}{|c|c|c|c|c|c|c|}
\hline \multirow{2}{*}{\multicolumn{2}{|c|}{ Kompetensi Dasar }} & Materi Pembelajaran & Kegiatan Pembelajaran & Penilaian & $\begin{array}{l}\text { Alokasi } \\
\text { Waktu }\end{array}$ & $\begin{array}{c}\text { Sumber } \\
\text { Belajar }\end{array}$ \\
\hline & & & $\begin{array}{l}\text { - Bereksperimen dengan beragam media } \\
\text { dan teknik } \\
\text { Menalar/Mengasosiasi } \\
\text { - Membandingkan konsep dan prosedur } \\
\text { mengambar dalam berbagai teknik } \\
\text { dan aliran seni rupa } \\
\text { Mengomunikasikan } \\
\text { - Membuat lukisan dengan } \\
\text { beragam media dan teknik } \\
\text { - Menyampaikan hasil } \\
\text { pengumpulan dan simpulan } \\
\text { informasi yang diperoleh } \\
\text { - Mempresentasikan secara lisan } \\
\text { atau tulisan mengenai karya } \\
\text { yang dikerjakan }\end{array}$ & $\begin{array}{l}\text { membuat gambar } \\
\text { Keterampilan: } \\
\text { - Projek } \\
\text { Membuat } \\
\text { lukisan dengan } \\
\text { beragam media } \\
\text { dan teknik } \\
\text { - Produk } \\
\text { Membuat } \\
\text { ringkasan } \\
\text { tentang konsep } \\
\text { dan prosedur } \\
\text { melukis dengan } \\
\text { beragam media } \\
\text { dan teknik }\end{array}$ & & \\
\hline 3.2. & $\begin{array}{l}\text { Memahami konsep dan } \\
\text { prosedur karya seni } \\
\text { patung dengan beragam } \\
\text { media dan teknik } \\
\text { Membuat karya seni } \\
\text { patung dengan beragam } \\
\text { media dan teknik }\end{array}$ & $\begin{array}{l}\text { Seni patung dengan } \\
\text { beragam media dan } \\
\text { teknik }\end{array}$ & $\begin{array}{l}\text { Mengamati } \\
\text { - Melihat patung dengan berbagai } \\
\text { teknik dan media yang berbeda } \\
\text { - Membaca buku tentang konsep dan } \\
\text { prosedur membuat patung } \\
\text { Menanya } \\
\text { - Menanyakan media yang murah yang } \\
\text { dapat digunakan dalam membuat } \\
\text { patung } \\
\text { - Menanyakan teknik membuat } \\
\text { patung } \\
\text { Mengumpulkan Informasi } \\
\text { - Menghubungkan antara konsep dan } \\
\text { prosedur patung dan konteks sosial } \\
\text { budaya masyarakat } \\
\text { - Mencari konsep dan prosedur }\end{array}$ & $\begin{array}{l}\text { Sikap: } \\
\text { - Observasi } \\
\text { tentang perilaku } \\
\text { peserta didik } \\
\text { dalam hal } \\
\text { kerjasama, } \\
\text { kedisipilan, } \\
\text { kebersihan, } \\
\text { penuh perhatian } \\
\text { dalam membuat } \\
\text { karya seni } \\
\text { patung dengan } \\
\text { beragam media } \\
\text { dan teknik. }\end{array}$ & $12 \mathrm{JP}$ & $\begin{array}{l}\text { - Buku } \\
\text { Teks } \\
\text { Pelajaran } \\
\text { Seni } \\
\text { Budaya } \\
\text { Kelas IX } \\
\text { - Buku- } \\
\text { buku lain } \\
\text { yang } \\
\text { relevan } \\
\text { - Informasi } \\
\text { melalui } \\
\text { internet } \\
\text { Pameran }\end{array}$ \\
\hline
\end{tabular}

\begin{tabular}{|c|c|c|c|c|c|}
\hline \multirow[t]{2}{*}{ Kompetensi Dasar } & Materi Pembelajaran & Kegiatan Pembelajaran & Penilaian & $\begin{array}{l}\text { Alokasi } \\
\text { Waktu }\end{array}$ & $\begin{array}{c}\text { Sumber } \\
\text { Belajar }\end{array}$ \\
\hline & & $\begin{array}{l}\text { membuat patung } \\
\text { - Bereksperimen dengan beragam media } \\
\text { dan teknik } \\
\text { Menalar/Mengasosiasi } \\
\text { - Membandingkan konsep dan } \\
\text { prosedur membuat patung dalam } \\
\text { kehidupan sosial budaya masyarakat } \\
\text { Mengomunikasikan } \\
\text { - Membuat karya seni patung } \\
\text { dengan beragam media dan teknik } \\
\text { - Menyampaikan hasil } \\
\text { pengumpulan dan simpulan } \\
\text { informasi yang diperoleh } \\
\text { - Mempresentasikan secara lisan } \\
\text { atau tulisan mengenai karya } \\
\text { yang dikerjakan }\end{array}$ & $\begin{array}{l}\text { Pengetahuan: } \\
\text { - Penugasan } \\
\text { Membuat prosedur } \\
\text { membuat patung } \\
\text { Keterampilan: } \\
\text { - Produk } \\
\text { Menyusun kritik } \\
\text { seni secara } \\
\text { sederhana } \\
\text { minimum } 300 \\
\text { kata tentang } \\
\text { konsep dan } \\
\text { prosedur } \\
\text { membuat seni } \\
\text { patung dengan } \\
\text { beragam media } \\
\text { dan teknik } \\
\text { - Projek } \\
\text { Membuat seni } \\
\text { patung dengan } \\
\text { beragam media } \\
\text { dan teknik }\end{array}$ & & $\begin{array}{l}\text { karya seni } \\
\text { Rupa }\end{array}$ \\
\hline $\begin{array}{l}\text { 3.3. Memahami konsep dan } \\
\text { prosedur karya seni grafis } \\
\text { dengan beragam media dan } \\
\text { teknik } \\
\text { 4.3. Membuat karya seni } \\
\text { grafis dengan beragam } \\
\text { media dan teknik }\end{array}$ & $\begin{array}{l}\text { Seni grafis dengan } \\
\text { beragam media dan } \\
\text { teknik }\end{array}$ & $\begin{array}{l}\text { Mengamati } \\
\text { - Melihat gambar dengan berbagai } \\
\text { teknik dan media yang berbeda } \\
\text { - Membaca buku tentang konsep dan } \\
\text { prosedur seni grafis } \\
\text { Menanya } \\
\text { - Menanyakan media yang murah yang } \\
\text { dapat digunakan dalam seni grafis } \\
\text { - Menanyakan teknik dan prosedur } \\
\text { seni grafis } \\
\text { Mengumpulkan Informasi }\end{array}$ & $\begin{array}{l}\text { Sikap } \\
\text { Observasi. } \\
\text { Tentang perilaku } \\
\text { peserta didik } \\
\text { dalam hal } \\
\text { kerjasama, } \\
\text { kedisipilan, } \\
\text { kebersihan, penuh } \\
\text { perhatian dalam } \\
\text { membuat karya } \\
\text { seni grafis dengan } \\
\text { beragam media } \\
\end{array}$ & $15 \mathrm{JP}$ & $\begin{array}{l}\text { - Buku } \\
\text { Teks } \\
\text { Pelajaran } \\
\text { Seni } \\
\text { Budaya } \\
\text { Kelas IX } \\
\text { - Buku- } \\
\text { buku lain } \\
\text { yang } \\
\text { relevan }\end{array}$ \\
\hline \multirow[t]{2}{*}{ Kompetensi Dasar } & Materi Pembelajaran & Kegiatan Pembelajaran & Penilaian & $\begin{array}{l}\text { Alokasi } \\
\text { Waktu }\end{array}$ & $\begin{array}{c}\text { Sumber } \\
\text { Belajar }\end{array}$ \\
\hline & & $\begin{array}{l}\text { - Menghubungkan antara konsep dan } \\
\text { prosedur hasil teknik grafis dalam } \\
\text { masyarakat } \\
\text { - Mencari berbagai media dalam } \\
\text { membuat gambar dalam seni grafis } \\
\text { - Bereksperimen dengan beragam media } \\
\text { dan teknik } \\
\text { Menalar/Mengasosiasi } \\
\text { - Membandingkan konsep dan prosedur } \\
\text { menggambar manual dalam seni } \\
\text { grafis } \\
\text { Mengomunikasikan } \\
\text { - Membuat gambar grafis dengan } \\
\text { beragam media dan teknik } \\
\text { - Mempresentasikan secara lisan atau } \\
\text { tulisan mengenai karya yang } \\
\text { dikerjakan }\end{array}$ & \begin{tabular}{|l} 
dan teknik. \\
Pengetahuan: \\
Penugasan \\
Membuat prosedur \\
membuat karya \\
seni grafis dengan \\
beragam media dan \\
teknik \\
Keterampilan: \\
- Produk \\
Membuat \\
ringkasan \\
tentang seni \\
grafis dengan \\
beragam media \\
dan teknik \\
- Projek \\
Membuat seni \\
grafis dengan \\
beragam media \\
dan teknik
\end{tabular} & & $\begin{array}{l}\text { - Informasi } \\
\text { melalui } \\
\text { internet } \\
\text { - Pameran } \\
\text { karya } \\
\text { seni } \\
\text { Rupa }\end{array}$ \\
\hline
\end{tabular}


Metode yang digunakan untuk pencarian data dalam penelitian ini adalah metode kualitatif. Data diperoleh dengan cara observasi langsung, kuesioner dan wawancara dengan responden. Subjek dari penelitian ini yaitu para guru Seni Budaya SMP se-Kawedanan Jatinom, Klaten, Jawa Tengah. Para guru tersebut tergabung dalam kelompok MGMP (Musyawarah Guru Mata Pelajaran) Seni Budaya Kawedanan Jatinom (Meliputi SMP di kecamatan Jatinom, Karanganom, Juwiring, Wedi, Ngawen, Polanharjo, Karangdowo, Cawas). Kelompok MGMP merupakan wadah para guru mata pelajaran Seni Budaya untuk meningkatkan mutu dan kualitas pembelajaran dalam mempersiapkan dan melaksanakan kegiatan belajar mengajar di sekolah.

Seperti yang dijelaskan pada latar belakang bahwa guru diwajibkan memilih 2 aspek seni dalam 2 semester setiap tahunnya. Jadi apabila pada semester pertama guru sudah memilih aspek seni rupa, maka pada semester kedua diwajibkan berganti aspek lain, misal seni musik, sehingga potensi kegiatan belajar mengajar seni grafis sangat jarang diminati atau dipilih oleh para guru, karena seni grafis masih kurang dikenal dan tekniknya lebih sukar dibandingkan dengan teknik-teknik dalam seni lukis. Selain itu alat dan bahan dalam membuat teknik seni grafis juga sukar didapatkan dan harganya kurang terjangkau. Sehingga pencarian informan guru yang pernah mengajar seni grafis cukup sukar ditemukan. Hal tersebut juga perlu dikaji dalam penelitian ini.

Penelitian menggunakan 3 responden dari sekolah yang berbeda. Ketiga responden ini dirasa cukup karena akan dapat menjadi pembanding, sehingga dari tiga sekolah ini nantinya akan diketahui perbedaan metode pengajaran dan pengalaman memberikan materi seni grafis. Sebelumnya penelitian ini sudah direncanakan dan telah dilaksanakan presurvei dari tanggal 14 Maret 2020, sehingga sebagian data sudah terkumpul. Sesuai dengan rencana kegiatan, selanjutnya proses pengumpulan data dilakukan dengan cara wawancara. Serta pengisian kuesioner melalui media Google Form juga disebarkan kepada responden. Ketiga data responden yang terpilih dan terkonfirmasi dapat dilihat pada Tabel 2.

Tabel 2. Informan Penelitian

\begin{tabular}{llll}
\hline No & \multicolumn{1}{c}{ Nama } & \multicolumn{1}{c}{ Jabatan } & \multicolumn{1}{c}{ Asal Sekolah } \\
\hline 1. & Adi & Guru & SMPN 3 Jatinom \\
& Prawito, S.Pd. & Seni Budaya & \\
\hline 2. & $\begin{array}{l}\text { Yulia Ujianita, } \\
\text { S.Pd. }\end{array}$ & Guru & SMPN 2 \\
& Seni Budaya & Karanganom \\
3. & Naurentina & Guru & SMPN 1 1 \\
& Nartani, S.Pd & Seni Budaya & Karanganom \\
\hline
\end{tabular}

Ketiga responden tersebut merupakan guru Seni Budaya yang sedang atau pernah mengajarkan materi seni grafis di kelas IX semester II dengan latar belakang bidang ilmu seni rupa. Tentunya responden itu mempunyai beragam pengalaman yang berbeda-beda mengenai kendala yang dihadapi dalam proses pembelajaran seni grafis. Penelitian ini menggunakan metode deskriptif dalam penyampaian hasil penelitian. Data yang didapatkan dari hasil wawancara dengan ketiga responden dijelaskan secara rinci dalam deskripsi. Penyusunan kesimpulan akan dilaksanakan berdasarkan hasil wawancara secara mendalam dan apa adanya sesuai dengan pengamatan terhadap responden. Penggunaan metode penelitian deskriptif kualitatif ini bertujuan untuk mengangkat dan mendalami sebuah masalah. Penelitian kemudian dijabarkan dalam sebuah analisis secara rinci hingga didapatkan kesimpulan yang sesuai dengan tujuan awal.

Penelitian dilaksanakan dengan beberapa tahapan, yang pertama adalah menyusun persiapan penelitian dengan melakukan studi pustaka. Pelaksanaan studi pustaka bertujuan untuk menelaah buku-buku dan referensi yang berkaitan dan relevan dengan pokok permasalahan. Mohammad Nazir dalam bukunya yang berjudul 'Metode Penelitian' mengemukakan bahwa yang dimaksud dengan 
"Studi kepustakaan adalah teknik pengumpulan data dengan mengadakan studi penelaahan terhadap buku-buku, literatur-literatur, catatancatatan, dan laporan-laporan yang ada hubungannya dengan masalah yang dipecahkan."(Nazir, 1988)

Selanjutnya, dilakukan pengumpulan data dengan menyiapkan pertanyaan-pertanyaan, baik secara langsung maupun menggunakan kuesioner google form. Seperti yang sudah sampaikan, bahwa sebelumnya sudah dilakukan wawancara secara langsung kepada responden. Namun karena pertanyaan yang diajukan merupakan pertanyaan spontan sehingga penulis membuat kuesioner agar data lebih terstruktur.

\section{Hasil dan Pembahasan}

Hasil wawancara dengan ketiga responden akan disajikan secara terpisah di bawah ini.

\section{Hasil wawancara responden 1}

Hasil yang didapatkan dari responden pertama, yaitu atas nama Bapak Adi Prawito, S.Pd., asal sekolah SMPN 3 Jatinom, bahwa beliau pernah mengajar seni grafis sekali di kelas IX semester II. Teknik seni grafis yang beliau ajarkan ternyata lebih kepada desain grafis atau desain komunikasi visual. Metode pengajarannya yaitu siswa diminta untuk menggambar atau membuat desain secara manual pada kertas gambar menggunakan pensil, misalnya desain baliho yang akan digunakan untuk pameran di sekolah, membuat desain poster dan sebagainya. Hasil dari gambar desain tersebut nantinya dicetak di tempat percetakan. Responden mendapatkan materi tersebut pada saat masih kuliah pendidikan S1 serta belajar pada percetakan. Berdasarkan pernyataan responden, siswa dapat memahami materi seni grafis tersebut dengan baik, namun dalam pengerjaan tugas, siswa hanya sampai pada tahap pembuatan desain. Hal ini disebabkan karena adanya kendala dalam pemenuhan kebutuhan bahan dan alat untuk proses selanjutnya. Guru memberikan solusi untuk melanjutkan ke proses cetak di percetakan.

\section{Hasil wawancara responden 2}

Berdasarkan kuesioner dan hasil dari wawancara kepada responden kedua atas nama Ibu Yulia Ujianita, S.Pd, asal sekolah SMPN 2 Karanganom, menjelaskan pernah mengajar materi seni grafis di kelas IX semester II. Materi yang diberikan adalah teknik seni grafis, cetak saring/stensil dengan bahan:
1. Kertas karton
2. Kertas gambar
3. Tinta bak

Untuk alat yang digunakan adalah:

1. Pensil,

2. Karet penghapus

3. Penggaris

4. Cutter (pisau pemotong)

5. Spon/ busa/ kapas untuk mewarnai pada buku gambar.

Proses pembuatannya adalah sebagai berikut: setelah menyiapkan alat dan bahan, tahap selanjutnya adalah membuat desain binatang kaki 4 pada kertas karton, lalu menghilangkan bidangbidang yang nantinya akan digunakan untuk mencetak (tinggal tersisa negatifnya) mnggunakan pisau cutter. Setelah selesai memotong atau melubangi bidang tersebut, tahap selanjutnya adalah menyiapkan buku gambar yang diletakkan di atas meja, kemudian cetakan dari karton diletakkan di atas kertas gambar. Selanjutnya ambil busa atau potongan spon dimasukkan atau dicelupkan pada tinta bak, kemudian ditutultutulkan pada cetakan hingga warna tinta berpindah pada permukaan buku gambar dan membentuk bentuk binatang kaki 4 .

Responden mengaku bahwa belum begitu mendalami teknik seni grafis, demikian juga ilmu tentang seni grafis masih sangat tipis. Karena pada saat kuliah responden merupakan jurusan kerajinan dan seni rupa, dan tidak mendapatkan materi seni grafis dan cara macam-macam mencetak, hanya pernah diajarkan memakai screen sablon namun proses pembuatannya tidak dilakukan dari awal. Dosen hanya mengajarkan 
proses mencetak (memindahkan cat warna menggunakan screen sablon).

Responden juga mengaku baru mengajar seni grafis satu kali semester yaitu pada saat awal pandemi Covid-19 kemarin. Serta siswa pada tahun sebelumnya belum pernah praktek (hanya diberikan teori dan penjelasan mengenai cara pembuatan). Hal ini disebabkan oleh faktor ekonomi, karena SMP 2 Karanganom merupakan SMP di desa (jauh dari kota) dengan ekonomi orang tua menengah ke bawah, sehingga untuk kegiatan praktikum sulit dilakukan karena masalah biaya. Jika menggunakan alternatif bahan lain selain masalah biaya, tempat penjualan alat dan bahan tersebut juga responden kurang tahu. Responden mendapatkan ilmu tentang seni grafis dan mempelajari teknik tersebut dari buku paket Seni Budaya kelas IX, modul seni budaya kelas IX dan internet.

Responden juga menjelaskan bahwa siswa belum begitu memahami materi seni grafis yang diajarkan, sehingga dalam pengerjaan tugas juga belum tuntas. Permasalahan yang dihadapi dalam mengajar seni grafis yang paling utama karena masalah biaya, mengingat kondisi orang tua ratarata kurang mampu. Serta anak kurang termotivasi dalam belajar seni grafis. Berkaitan dengan solusi atas kendala yang dihadapi, responden menjelaskan bahwa masalah kondisi orang tua tidak bisa ditawar, namun masalah anak perlu ada bimbingan dari orang yang lebih ahli dalam seni grafis, khususnya materi praktikum.

\section{Hasil wawancara responden 3}

Pengisian kuesioner dan wawancara kepada responden ketiga atas nama Laurentina Niken Nartani, S.Pd. asal sekolah SMPN 1 Karanganom, menghasilkan informasi bahwa responden pernah mengajar seni grafis di kelas IX semester II yaitu teknik cetak tinggi dan cetak dalam. Responden mendapatkan ilmu tentang seni grafis dari materi kuliah pada saat mengenyam pendidikan di Universitas Sarjanawiyata Taman Siswa. Teknik seni grafis yang diajarkan menggunakan alat, yaitu (1) Alat cukil (cutter atau solder); dan (2) Pensil/bolpoin, serta bahan: (1) Spon hati; (2) Cat diganti dengan tinta cap; (3) Kain untuk taplak; dan (4) Kertas.

Proses pembuatan: langkah pertama yaitu membuat pola/gambar pada kertas menggunakan pensil, lalu pola dipindahkan pada permukaan spon hati. Proses selanjutnya spon hati dicukil menggunakan alat cukil bisa menggunakan cutter atau solder listrik. Setelah permukaan spon hati dicukil sesuai pola, tahap selanjutnya yaitu spon hati yang sudah dicukil dicapkan pada kain/kertas menggunakan tinta cap.

Dengan diajarkannya teknik seni grafis tersebut, responden mengaku bahwa siswa dapat memahami materi tersebut, serta siswa dengan senang mengerjakan tugas seni grafis. Kendala yang dihadapi masih sama dengan responden kedua yaitu masalah ekonomi, karena siswa harus membeli alat dan bahan masing-masing. Berkaitan dengan kendala tersebut responden mencari solusi untuk mencarikan alat dan bahan yang lebih murah, yaitu dengan spon hati dipotong-potong kecil, sehingga bisa digunakan oleh beberapa siswa. Serta pengerjaan tugas seni grafis tersebut dilakukan secara berkelompok.

\section{Kesimpulan}

Berdasar hasil penggalian data dari ketiga responden tersebut dapat disimpulkan bahwa reponden pertama memberikan materi seni grafis disain komunikasi visual, bukan mempelajari mengenai berbagai teknik mencetak dalam seni grafis, misal teknik cetak tinggi, cetak dalam, cetak datar, cetak saring/ sablon, namun yang diajarkan hanya sampai tahap membuat desain grafis secara manual. Saran dalam kegiatan proses pembelajaran seni grafis ini diharapkan dapat menggunakan teknik yang lebih sederhana, menggunakan alat dan bahan yang mudah ditemukan. Serta memilih teknik yang mudah dalam proses mencetaknya, sehingga siswa tidak perlu menggunakan jasa percetakan dalam mencetak karya tugas. Sehingga siswa lebih memahami bagaimana proses cetak tersebut dilakukan.

Untuk responden kedua, walaupun guru 
merasa kurang mampu dalam memberikan materi seni grafis, namun kegiatan pembelajaran yang sudah dilakukan sangat bagus dan menarik. Teknik yang diajarkan merupakan teknik cetak saring (stensil) secara sederhana. Dengan melubangi bagian tertentu menyesuaikan bentuk pola, dan diberi warna menggunakan cat sederhana. Hal ini sudah memenuhi capaian pembelajaran seni grafis, walaupun siswa belum bisa mengerjakan praktikum teknik tersebut namun, secara pemahaman siswa diharapkan sudah memahami teknik tersebut dengan baik.

Berdasarkan hasil wawancara dengan responden ketiga, ternyata responden ini lebih menguasai teknik seni grafis dibandingkan dengan responden lain. Hal ini dikarenakan responden mendapatkan ilmu dan sudah mengaplikasikan pada saat mengenyam pendidikan perkuliahan di jenjang $S 1$. Hal demikian menunjukkan bahwa pembekalan untuk guru dirasa sangat penting dan bermanfaat dalam mengoptimalkan potensi guru mengajar seni grafis. Penggunaan alat yang ekonomis dan mudah didapatkan juga menjadi poin penting dalam pembelajaran praktikum seni grafis. Strategi untuk membuat karya tugas secara berkelompok menjadi solusi yang baik di pembelajaran tersebut.

Dari ketiga responden tersebut ternyata pembelajaran seni grafis di SMP se-Kawedanan Jatinom, Klaten, Jatinom, sudah cukup optimal, hanya saja masih ada guru yang belum mengerti dan mempelajari ilmu seni grafis secara mendalam.

Saran berdasarkan hasil dari pengumpulan data pada penelitian ini, yaitu:

a. Guru seni budaya dapat mencari referensi materi pembelajaran seni grafis dari berbagai sumber, misal bisa dari buku pelajaran, bukubuku seni grafis, mengikuti workshop seni grafis, atau bisa juga mencari di internet.

b. Agar lebih optimal, selain guru berkewajiban mencari materi dari berbagai sumber, guru juga harus memperhitungkan kebutuhan alat dan bahan dalam pelaksanaan pembelajaran seni grafis tersebut. Sehingga tidak akan memberatkan siswa dan orang tua wali dalam segi materil. Misal dapat dengan cara mengusulkan penganggaran inventaris sekolah, alat dan bahan disediakan oleh sekolah atau juga bisa dilakukan secara berkelompok dalam pengerjaan tugasnya. Upaya selanjutnya juga dapat dilakukan dengan iuran untuk membeli kebutuhan alat dan bahan yang bisa digunakan bersamasama.

c. Selain itu, di era digital apalagi dalam kondisi pandemic Covid-19 ini, guru bisa membuat materi berupa video tutorial yang nantinya bisa dibagikan dan dipelajari siswa, walaupun tugasnya bukan mempraktikan teknik seni grafis, namun berdasarkan video tutorial teknik seni grafis tersebut dapat dibuat kuis atau kegiatan tanya jawab. Siswa dapat menuliskan apa yang dipahami dalam video tersebut. Apabila tidak memungkinkan dalam pembuatan video tutorial oleh guru, guru dapat mencari referensi-referensi video dari internet sebagai bahan untuk diajarkan kepada siswa.

d. Perlu diadakan workshop mengenai seni grafis oleh seseorang yang ahli dalam bidangnya, dan atau pembuatan model pembelajaran sesuai dengan kurikulum K13 Seni Budaya SMP, misalnya berupa video tutorial atau buku bahan ajar agar memudahkan dan membantu guru-guru dalam mengajarkan materi seni grafis kepada siswa.

\section{Kepustakaan}

Bentara Budaya Jakarta. (2000). Setengah Abad Seni Grafis Indonesia, Half a Century of Indonesian Printmaking, Jakarta: KPG (Kepustakaan Populer Gramedia) dan Bentara Budaya Jakarta.

Indonesia, Kementerian Pendidikan dan Kebudayaan. (2017). Seni Budaya Kelas IX, Jakarta: Kementerian Pendidikan dan Kebudayaan.

Indonesia, Kementerian Pendidikan dan Kebudayaan. (2018). Seni Budaya : Buku Guru, Jakarta: Kementerian Pendidikan dan 
Kebudayaan.

Medley, Christine. (2020). Printmaking: How to Print Anything on Everything, New York: Dover Publications.

Oktanio, Fery. (2010). In Repair: Imagination of Resistance and An Idea of Superhuman, Katalog Pameran Seni Grafis "In Repair" Ariswan Adhitama, Yogyakarta: Bentara Budaya Yogyakarta.
Sandra, Yofita. (2012). Silabus, Sap, Dan Bahan Ajar Seni Grafis Dasar, Padang: Jurusan Pendidikan Seni Rupa Fakultas Bahasa Dan Seni Universitas Negeri Padang.

Sulastianto, Harry, dkk. (2007). Seni Budaya untuk Kelas IX Sekolah Menengah Pertama, Bandung: Grafindo Media Pratama.

Tanama, Andre, (2020). Cap Jempol, Seni Grafis dari Nol, Yogyakarta: Penerbit SAE. 